\title{
Serotype-Specific Serum IgG Antibodies to Lipopolysaccharides of Pseudomonas aeruginosa in Cystic Fibrosis: Correlation to Disease, Subclass Distribution, and Experimental Protective Capacity
}

\author{
URS B. SCHAAD, ALOIS B. LANG, JOANNA WEDGWOOD, UELI BUEHLAMNN, AND \\ EMIL FUERER
}

Department of Pediatrics (Inselspital), University of Berne [U.B.S., J.W., U.B.], and Swiss Serum and Vaccine Institute, Berne [A.B.L., E.F.], Switzerland

\begin{abstract}
Various studies have demonstrated pronounced systemic IgG response to Pseudomonas aeruginosa (PA) infection in cystic fibrosis (CF). However, antibody response to serotype-specific lipopolysaccharides (LPS) has never been studied. ELISA for detection of IgG antibodies to LPS of nine PA-serotypes and to toxin A were performed with serum of $78 \mathrm{CF}$ patients. Anti-LPS profiles of antibodies were confirmed by SDS-PAGE and immunoblotting techniques. The most frequent PA-serotypes found were immunotypes (IT) IT- 1 and IT-2, and Habs-3 and Habs-4. Ten patients without PA colonization showed no detectable antibody titers. In patients with chronic PA colonization $(n=46)$, these antibody titers were significantly $(p<0.005)$ higher than in patients with intermittent PA colonization $(n=22)$. Mean serum antibody titers to LPS of PA IT-1, IT-2, Habs-3, and Habs-4 correlated with duration of PA colonization and with disease severity. Subclass analysis of anti-LPS antibodies revealed elevated levels for all four IgG subclasses and for $\operatorname{IgA} A_{1}$. The IgG antibodies to LPS of PA proved to be protective in a murine burn wound sepsis model. We conclude that anti-LPS antibodies to specific PA serotypes in serum may be a sensitive measure of severity and prognosis of $C F$. Patients with $C F$ show adequate functional immune response to LPS of $\mathrm{PA}$, and it is possible that vaccination against PA before colonization could induce protective immunity. (Pediatr Res 27: 508-513, 1990)
\end{abstract}

Abbreviations

CF, cystic fibrosis

IT, immunotype

LPS, lipopolysaccharide

PA, Pseudomonas aeruginosa

Tox A, toxin A

$\mathrm{PA}$ is a persistent sputum pathogen in most patients with advanced CF (1). Pseudomonas pulmonary infections are the major determinant of quality and duration of life in these patients. Mechanisms of virulence and pathogenesis of PA are

Received September 19, 1989; accepted January 3, 1990.

Correspondence and requests for reprints: Urs B. Schaad, M.D. Division of Pediatric Infectious Diseases, Department of Pediatrics, University of Berne, Inselspital, CH-3010 Berne, Switzerland. extremely complex and include invasiveness and toxigenicity $(2$, 3). Moreover, direct and indirect evidence of induction of immunologic damage by PA has been repeatedly reported (2-5).

CF patients infected and colonized by PA produce substantial $\mathrm{IgG}$ serum antibody titers against a variety of PA antigens, including exoproteins $(6,7)$, cell surface structures $(8,9)$, outermembrane proteins $(10)$, water-soluble antigens $(11,12)$, and LPS $(13,14)$. The majority of these antibodies against PA antigens was shown to correlate with $\mathrm{CF}$ disease severity and prognosis (5-14). These antibodies are unable to stop the spread of bacteria in the lungs and the resultant tissue destruction in advanced $\mathrm{CF}$.

The purpose of our investigations was to measure antibody response to serotype-specific LPS in patients with CF and to correlate these titers with PA colonization/infection and disease stage. Moreover, we compared $\mathrm{IgG}$ and $\mathrm{IgA}$ subclass distribution of antibodies against PA from sera of CF patients and healthy individuals immunized with PA conjugate vaccine. Finally, protection against PA infection in a murine burn wound sepsis model was studied by passive transfer of $\mathrm{IgG}$ derived from sera of CF patients and healthy individuals immunized with PA conjugate vaccine.

\section{MATERIALS AND METHODS}

Study patients. Between January 1987 and June 1988, 78 patients with $\mathrm{CF}$ attending the $\mathrm{CF}$ clinic at our hospital were studied. There were no inclusion or exclusion criteria regarding age or disease severity, but patients were not enrolled during acute bronchopulmonary exacerbation. The patients were 1-27 $\mathrm{y}$ old (mean $\pm \mathrm{SD}, 14.7 \pm 6.2 \mathrm{y}$ ), 40 were female, and 38 were male. Ten patients had no PA colonization, 22 patients were classified as intermittently colonized with PA on the basis of intermittent growth of PA in sputum, and 46 patients were classified as chronically colonized on the basis of three or more positive sputum cultures over at least $1 \mathrm{y}$. Each patient was only studied once. The trial was approved by the hospital ethics committee, and the patients or their parents gave informed consent.

Serum samples were obtained by venipuncture and frozen at $-20^{\circ} \mathrm{C}$ until tested. The patients were assigned to various categories for each of the following criteria: age, duration of PA colonization, degree of underweight, $\mathrm{CF}$ score, radiographic score, and vital capacity. Correlations between the categories and mean serum antibody titers were assessed graphically. Underweight was determined as percent of predicted wt for age (15). The CF scoring system used included physical activity, findings 


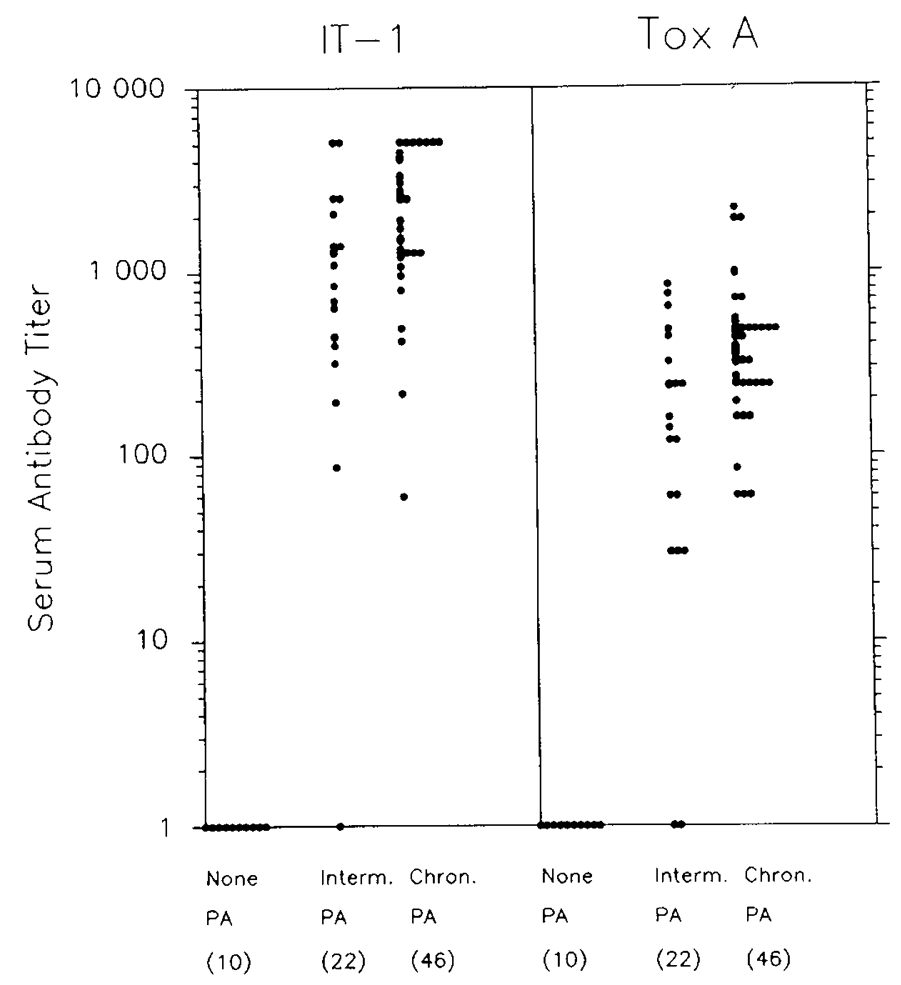

Fig. 1. Distribution of serum antibody titers against LPS of IT- 1 and Tox A in the three CF patient groups according to their PA colonization status: none $(n=10)$, intermittent $(n=22)$ and chronic $(n=46)$.

Table 1. Serum antibody titers to LPS of PA serotypes IT-I, IT-2, Habs-3, Habs-4, and Tox A in CF patients intermittently or chronically colonized with $P A^{*}$

\begin{tabular}{lccc}
\hline $\begin{array}{c}\text { Antibody } \\
\text { titer to: }\end{array}$ & $\begin{array}{c}\text { Intermittent PA } \\
\text { colonization }(n=22)\end{array}$ & $\begin{array}{c}\text { Chronic PA } \\
\text { colonization }(n=46)\end{array}$ & $p$ value† \\
\hline IT-1 & $1508 \pm 1611$ & $2713 \pm 1632$ & $<0.005$ \\
& $(0-5125)$ & $(60-5125)$ & \\
IT-2 & $374 \pm 619$ & $1369 \pm 1546$ & $<0.005$ \\
& $(0-2560)$ & $(0-5125)$ & \\
Habs-3 & $414 \pm 485$ & $1158 \pm 1191$ & $<0.005$ \\
& $(0-1280)$ & $(0-5120)$ & \\
Habs-4 & $463 \pm 654$ & $1369 \pm 1487$ & $<0.05$ \\
& $(0-2560)$ & $(0-5125)$ & \\
Tox A & $247 \pm 244$ & $484 \pm 457$ & $<0.005$ \\
& $(0-844)$ & $(60-2200)$ & \\
\hline
\end{tabular}

$*$ Values are mean \pm SD (range).

$\dagger$ Wilcoxon-Mann-Whitney rank sum test.

on physical examination and in sputum, signs of pulmonary disease, radiologic lung involvement, and gastrointestinal manifestations $(15,16)$. Each of these variables was rated on a scale of 1 to 5 points, with the highest score indicating the best status. Posteroanterior and lateral chest radiographs were graded by a pediatric radiologist according to the Chrispin-Norman scoring system (17), ranging from 0 (normal chest roentgenogram) to 38 (maximal lung and chest abnormalities in CF). Vital capacity was measured in a volume-constant whole-body plethysmograph (18) and expressed as percentage of predicted value for ht.

Vaccine studies were performed in 18 healthy volunteers of both sexes 19-45 y old. Their written informed consent was obtained according to the approval of the institutional research committee.

Purification of antigens. Tox A was purified from PA-103 as previously described (19). LPS was extracted from cell wall fragments of the nine most frequently isolated PA-serotypes (IT1 to IT-7 according to Fisher, and Habs-3 and Habs-4) according to methods described in detail elsewhere (20). PA strains were serotyped by slide agglutination with suitably diluted antisera against the 17 O-type strains of the International Antigenic Typing System (21).

ELISA. ELISA for the quantitation of antibodies to LPS and Tox A in patients' serum samples were performed in the following manner (19). Microtiter plates (Dynatech, Kloten, Switzerland) were coated with $200 \mu \mathrm{L}$ of LPS $(10 \mu \mathrm{g} / \mathrm{mL})$ of Tox A $(10$ $\mu \mathrm{g} / \mathrm{mL}$ ) by incubation at $37^{\circ} \mathrm{C}$ for $3 \mathrm{~h}$. For coating, the LPS was suspended in PBS and Tox A in $0.1 \mathrm{M}$ sodium carbonate, $\mathrm{pH}$ 9.6. Sera were diluted in PBS containing $0.02 \%$ Tween 20 and $200 \mu \mathrm{L}$ of each dilution were added per well. After the addition of the substrate solution (ABTS, Boehringer-Mannheim, Mannheim, FRG), color was allowed to develop for $10 \mathrm{~min}$. Absorbancy at $405 \mathrm{~nm}$ was measured with a Titertek Multiscan (Flow Laboratories, Hamden, CT) (22). Titers were expressed as the reciprocal of the highest dilution of serum yielding 0.4 of maximal absorbancy. The specificity of the assay was confirmed by measuring crossreactivity to Escherichia coli LPS and Salmonella typhi Ty21a LPS.

SDS-PAGE and immunoblots. SDS-PAGE was performed by the method of Laemmli (23). A 7.5-15\% linear gradient acrylamide gel was used, and $4 \mu \mathrm{g}$ of purified PA LPS and $2 \mu \mathrm{g}$ of purified Tox A in SDS-sample buffer were applied per well. For immunoblot analysis, the samples were electrophoretically transferred to nitrocellulose sheets as described (24). The sheets were incubated sequentially with serum of CF patients diluted at 1:100 to $1: 500$, peroxidase-labeled, affinity-purified goat anti-human IgG-M-A (Kirkegaard and Perry, Gaithersburg, MD), and with 4-chloro-1-naphthol substrate (Bio-Rad, Glattbrugg, Switzerland). An identical gel was used for silver staining by the method of Tsai and Frasch (25).

$\operatorname{Ig} G$ and $I g A$ subclass analysis. For determination of human $\mathrm{IgG}$ and IgA subclasses, an ELISA was performed as previously described (26). The following subclass-specific murine MAb were used: anti-human $\mathrm{IgG}_{1}$ (clone $\mathrm{HP6012}$ ), anti-human $\mathrm{IgG}_{3}$ (HP6010), anti-human $\mathrm{IgG}_{4}$ (HP6011), anti-human $\operatorname{Ig} \mathrm{A}_{1}$ (BAM12), anti-human $\operatorname{Ig} \mathrm{A}_{2}$ (M27010) (Unipath Limited, Bedford, England), and anti-human $\mathrm{IgG}_{2}$ (HP6014) (Sigma Chemicals Co., St. Louis, MO). As a second antibody, a horseradishperoxidase conjugated goat anti-mouse IgG (Bio-Rad Laboratories, Richmond, CA) was used. After addition of substrate, the $\mathrm{OD}$ at $405 \mathrm{~nm}$ was determined as described above.

Burn wound model. The murine burn wound sepsis model of Stieritz and Holder (27) was used with slight modification as previously described (19). The mice (in groups of six) received $160 \mu \mathrm{g}$ of $\operatorname{IgG}$ in a volume of $0.2 \mathrm{~mL}$ via the tail vein $24 \mathrm{~h}$ before the challenge with strain PA-220, s.c. injected into the burned area. During induction of burns, the animals were carefully anesthesized in an atmosphere of methoxyflurane (19).

Statistical analysis. Antibody titers are expressed as means \pm 1 SD. Differences between the patient groups were tested for significance by the Wilcoxon-Mann-Whitney rank sum test (28).

\section{RESULTS}

Serum antibodies. The $10 \mathrm{CF}$ patients without PA colonization/infection showed no detectable antibody titers to PA LPS or Tox A. The $68 \mathrm{CF}$ patients with intermittent $(n=22)$ or chronic $(n=46)$ PA bronchopulmonary colonization/infection had elevated serum antibody titers to LPS of IT-1 in 97\%, to IT2 in $69 \%$, to Habs-3 in $74 \%$, to Habs- 4 in $71 \%$, and to Tox A in $94 \%$, whereas antibodies to LPS of IT-3, IT-4, IT-5, IT-6, and IT-7 were found in $<5 \%$. In Figure 1 , the distribution of the two most frequently detected serum antibody titers-to LPS of IT-1 and to Tox A-are shown for the three patient groups. As listed in Table 1, these antibody titers were significantly higher in 

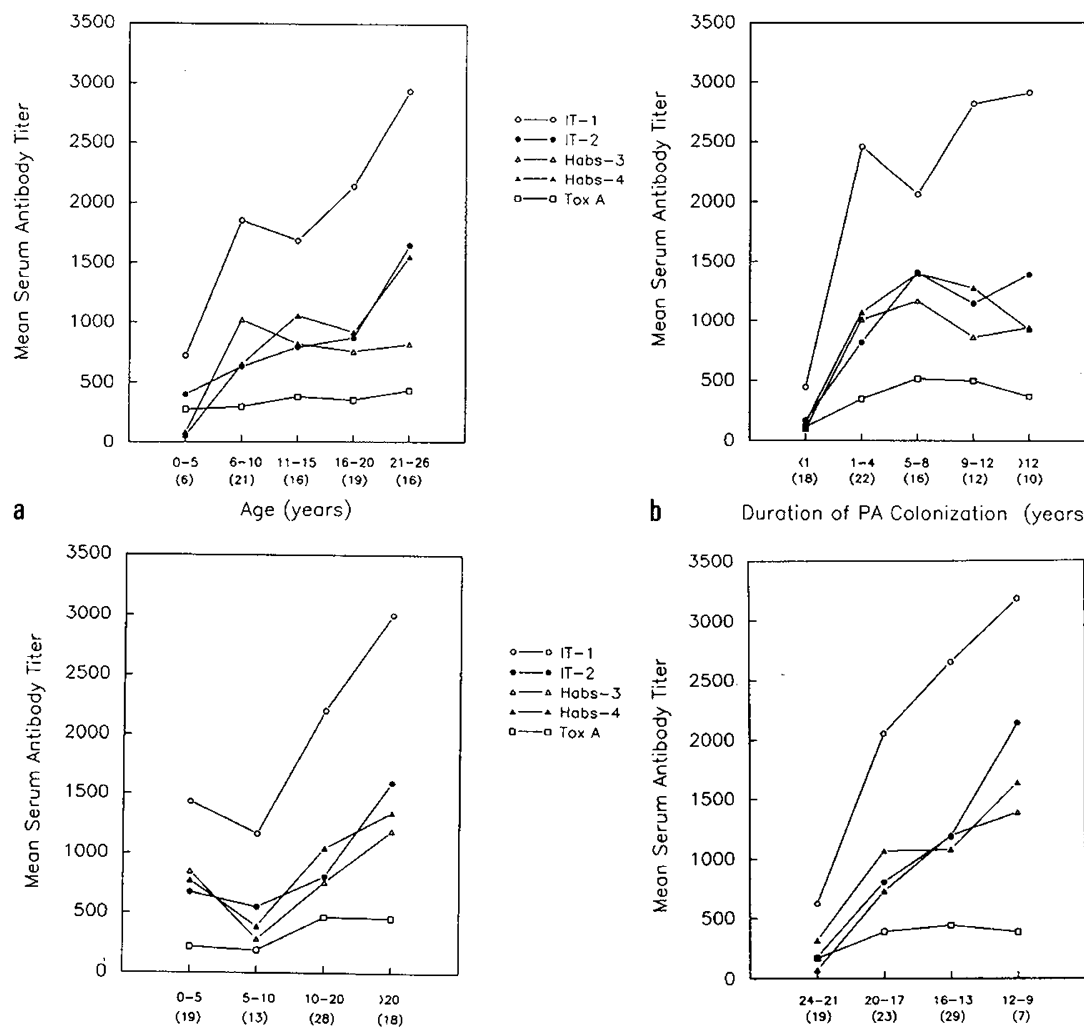$$
\text { 列 }
$$
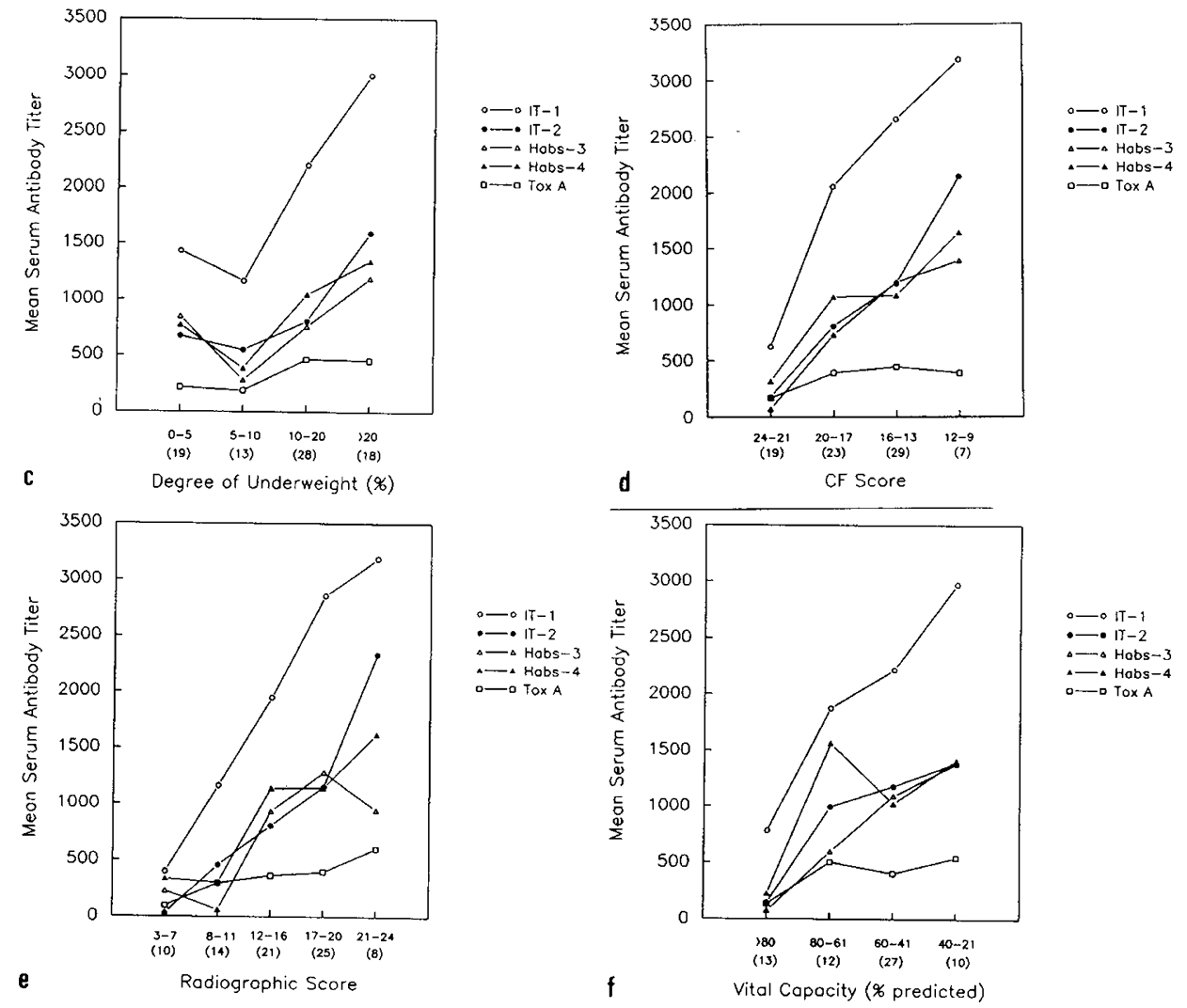

Fig. 2. Study patients were assigned to one of four or five categories for age $(a)$, duration of PA colonization $(b)$, degree of underweight $(c), \mathrm{CF}$ score $(d)$, radiographic score $(e)$, and vital capacity $(f)$. The correlations of the mean serum antibody titers to LPS of IT-1, IT-2, Habs-3, Habs-4, and Tox A with these different disease stages are shown. Number of patients in parentheses.

patients chronically colonized compared to those intermittently colonized with PA

PA cultured and isolated from sputum of six CF patients were serotyped and reflected the common types found for the serum antibody titers: Habs-4 (5x), IT-1 (3×), and Habs-3 $(2 \times)$.

Graphic correlation of mean serum antibody titers with patient age, duration of PA colonization, degree of underweight, CF score, radiographic score, and vital capacity are shown in Figures $2 a-f$. Statistical analysis was considered inapplicable (28).

SDS-PAGE and immunoblotting. These techniques confirmed the anti-PA LPS-specific profile of the serum antibodies measured (Fig. 3) by reaction with the O-side chain region of LPS of IT-1, IT-2, and Habs-3.

Subclasses. The results of IgG and IgA subclass analysis of serum antibody titers to LPS of PA IT-1, to PA Tox A, and to tetanus toxin are presented in Table 2. Pooled serum from 10 adolescent $\mathrm{CF}$ patients with chronic PA colonization, with similar antibody titers, and with tetanus immunization status according to recommended schedules was compared to pooled serum from 18 healthy adult volunteers before and $28 \mathrm{~d}$ after active immunization with PA IT-1 polysaccharide-tetanus toxoid conjugate vaccine. Anti-IT-1-LPS titers in CF patients were substantially higher for all four IgG subclasses, and also for IgA 1 , compared to the vaccine response in healthy individuals. Antitetanus-toxin titers in CF patients and in unvaccinated volunteers showed similar IgG and IgA subclass distribution.

Burn wound model. Table 3 shows the protection against PA infection in a murine burn wound sepsis model by passive transfer of $\mathrm{IgG}$ derived from sera of 10 adolescent $\mathrm{CF}$ patients chronically colonized with PA (with similar antibody titers to PA LPS) and from sera of 18 healthy adult volunteers before and $28 \mathrm{~d}$ after immunization with PA IT-1 polysaccharidetetanus toxoid conjugate vaccine. IgG antibodies isolated from $\mathrm{CF}$ sera were equally protective compared to those isolated from postimmunization sera, whereas IgG antibodies from preimmunization sera were only slightly more effective than control albumin, explained by preexisting specific antibodies.

\section{DISCUSSION}

Numerous studies have demonstrated an inverse correlation between serum antibody titers against a variety of relatively 


\section{IT-1 IT-2 IT-3 IT-4 IT-5 Habs -3 Habs-4 E.coli}
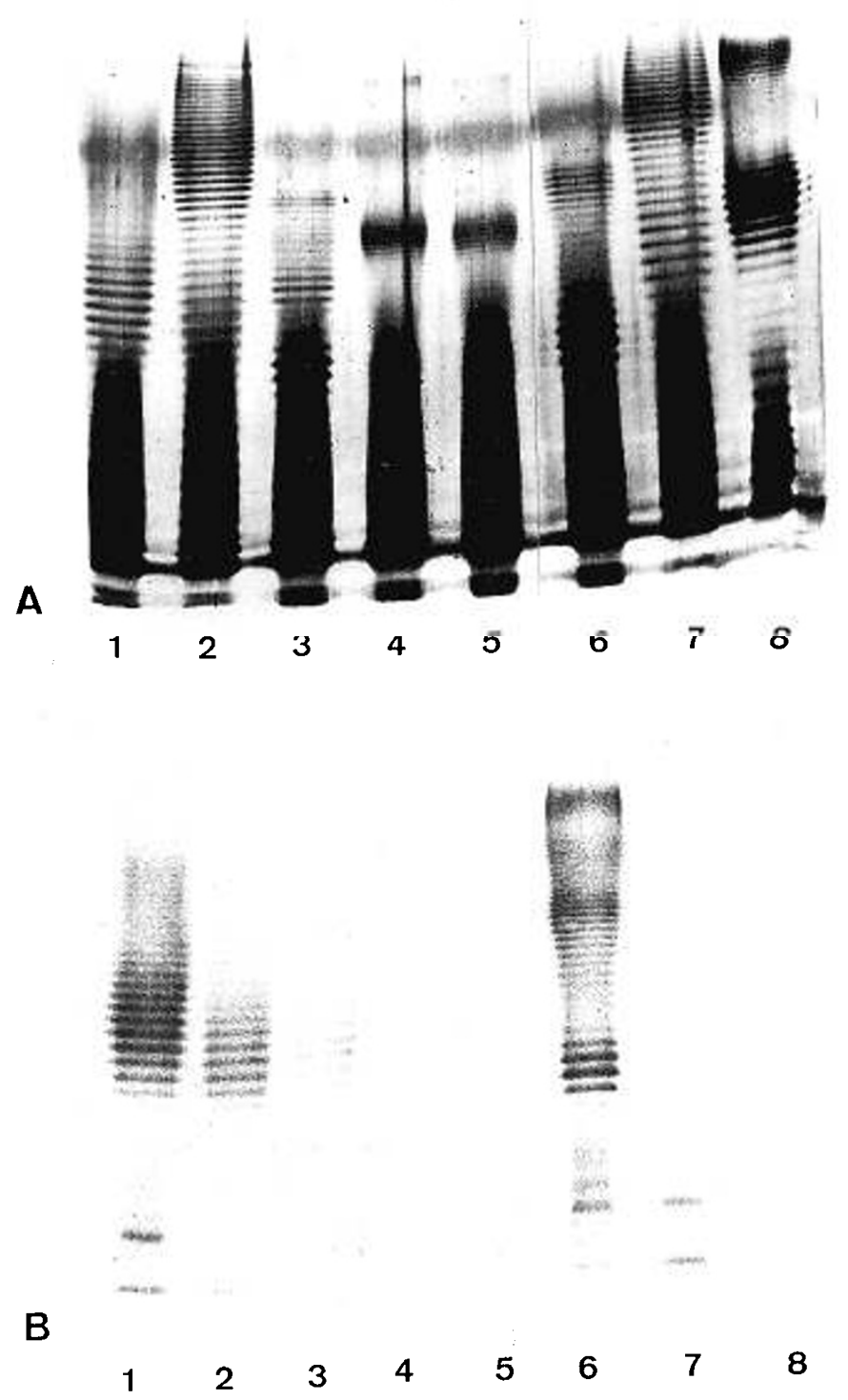

Fig. 3. SDS-PAGE and immunoblotting technique. Purified LPS derived from PA IT-1 to IT-5 (lanes 1-5), from Habs-3 and Habs-4 (lanes 6 and 7), and from $E$. coli (lane 8) were each subjected to SDS-PAGE $(A)$, gel developed by silver-staining; $(B)$, immunoblot with serum of a CF patient diluted 1:1000, showing bands in the O-side chain region of smooth-type LPS of IT-1, IT-2, and Habs-3.

Table 2. IgG and IgA subclass distribution of antibody titers in pooled serum from CF patients chronically colonized with $P A$ and from healthy individuals before and after PA IT-1 polysaccharide-tetanus toxoid conjugate vaccine

\begin{tabular}{|c|c|c|c|c|c|c|c|c|c|c|c|c|c|c|c|c|c|c|}
\hline \multirow[b]{2}{*}{ Source of serum pool } & \multicolumn{6}{|c|}{ Anti-IT-1-LPS titers } & \multicolumn{6}{|c|}{ Anti-PA-Tox A titers } & \multicolumn{6}{|c|}{ Antitetanus-toxin titers } \\
\hline & $G_{l}$ & $\mathrm{G}_{2}$ & $\mathrm{G}_{3}$ & $\mathrm{G}_{4}$ & $\mathrm{~A}_{1}$ & $\mathrm{~A}_{2}$ & $G_{1}$ & $\mathrm{G}_{2}$ & $\mathrm{G}_{3}$ & $\mathrm{G}_{4}$ & $\mathrm{~A}_{1}$ & $\mathrm{~A}_{2}$ & $G_{l}$ & $\mathrm{G}_{2}$ & $\mathrm{G}_{3}$ & $\mathrm{G}_{4}$ & $\mathrm{~A}_{1}$ & $\mathrm{~A}_{2}$ \\
\hline CF patients $(n=10)$ & 1280 & 1290 & 210 & 120 & 550 & 0 & 260 & 50 & 40 & 60 & 70 & 0 & 80 & 40 & 0 & 40 & 0 & 0 \\
\hline $\begin{array}{l}\text { Healthy individuals }(n=18) \\
\text { preimmunization }\end{array}$ & 0 & & 0 & 0 & 0 & 0 & $\mathrm{ND}^{*}$ & ND & ND & ND & $\begin{array}{l}\text { ND } \\
\text { ND }\end{array}$ & $\begin{array}{l}\text { ND } \\
\text { ND }\end{array}$ & $\begin{array}{r}120 \\
5120\end{array}$ & $\begin{array}{r}20 \\
460\end{array}$ & $\begin{array}{r}0 \\
110\end{array}$ & $\begin{array}{r}30 \\
1510\end{array}$ & $\begin{array}{r}0 \\
20\end{array}$ & $\begin{array}{l}0 \\
0\end{array}$ \\
\hline
\end{tabular}

* Not done.

unspecific PA antigens and stage of CF disease (6-14). There is clear support for the hypothesis that the pronounced antibody response to PA antigens has deleterious effects because of immune complex-induced destruction of lung tissue $(3-5,11,13)$.

This study reports for the first time results of serum IgG antibodies to LPS of the nine most frequently isolated serotypes of PA in patients with CF. Anti-LPS profile of these antibodies was confirmed by PAGE and immunoblotting techniques. The most common PA types in our CF population are IT-1, IT-2,
Habs-3, and Habs-4. Mean serum antibody titers to LPS of these four serotypes correlated with duration of PA colonization/ infection, and with disease severity as reflected by chronologic age, underweight, CF and radiographic scores, and vital capacity. These correlations with the anti-Tox A-titers were clearly less pronounced than those with the serotype-specific antibody responses, which is in certain contrast to other reports $(7,13)$.

Currently, there is considerable interest in the role of $\mathrm{IgG}$ subclasses in CF (29-31). Recently, R. B. Moss et al. (31) have 
Table 3. Mean $L D_{50}$ of PA-220 in a murine burn wound sepsis model after passive transfer of IgG derived from sera of $C F$ patients chronically colonized with PA and from healthy individuals before and after PA IT-1 polysaccharide-tetanus toxoid conjugate vaccine

\begin{tabular}{|c|c|c|c|c|}
\hline \multirow[b]{2}{*}{ IgG derived from serum of: } & \multirow[b]{2}{*}{ Mean $\mathrm{LD}_{50}{ }^{*}$} & \multicolumn{3}{|c|}{ Antibody titers to: } \\
\hline & & LPS PA-220 & PA Tox A & Tetanus toxin \\
\hline Patient CF-6 & $9.4 \times 10^{5}$ & 900 & 240 & 480 \\
\hline Patient CF-9 & $1 \times 10^{6}$ & 1280 & 160 & 420 \\
\hline Patient CF-24 & $5 \times 10^{6}$ & 980 & 240 & 540 \\
\hline CF pool $(n=10)$ & $9.4 \times 10^{5}$ & 1120 & 160 & 394 \\
\hline \multicolumn{5}{|l|}{ Healthy individuals $(n=18)$} \\
\hline preimmunization & $2 \times 10^{3}$ & 45 & $\mathrm{ND}+$ & 260 \\
\hline postimmunization & $9.4 \times 10^{5}$ & 560 & ND & 1280 \\
\hline Control albumin & $3 \times 10^{2}$ & & & \\
\hline
\end{tabular}

\footnotetext{
* Groups of six mice were used for each challenge dose.

+ Not done.
}

reported altered serum antibody isotype response to heptavalent LPS of PA in patients with CF. Based on in vitro studies (mouse alveolar macrophage phagocytosis of PA) this research group proposed a possible role in opsonic deficiency by increased levels of $\mathrm{IgG}_{4}$ antibodies which could contribute to impaired pulmonary clearance of PA (30). Our results confirmed that CF patients colonized with PA develop elevated serum levels of all four IgG subclass antibodies to LPS of PA, whereas healthy individuals only respond with $\mathrm{IgG}_{1}$ and $\mathrm{IgG}_{2}$ antibodies to PA conjugate vaccine. IgA subclass analysis of serum Anti-LPS-antibodies revealed exclusive $\operatorname{Ig} A_{1}$ response in both $\mathrm{CF}$ patients and immunized controls. Brandtzaeg et al. (32) have shown that IgA synthesis dominates among immunocytes producing secretory $\operatorname{IgA}$ in the upper part of the body (respiratory tract) and $\operatorname{IgA}_{2}$ in the lower part (gastrointestinal tract).

In a murine burn wound sepsis model, we have previously demonstrated the serotype-specific protective capacity of IgG antibodies to LPS of PA isolated from rabbit hyperimmune sera (19). In contrast, passive transfer of anti-Tox A or antielastase IgG antibodies did not significantly alter the experimental PA infection (19). Sawada et al. (33) have confirmed these findings in the same animal model with MAb produced by mouse hybridoma cells. In this study we found that the $\operatorname{IgG}$ antibodies to LPS of PA derived from CF sera were as protective as those derived from postimmunization sera of healthy controls.

In conclusion, our results indicate that anti-LPS antibodies to specific PA-serotypes in serum may be a sensitive measure of severity and prognosis of CF. Longitudinal studies are warranted to confirm this hypothesis. The role of $\operatorname{IgG}$ and $\operatorname{IgA}$ subclass distribution of antibody response to LPS of PA requires further investigation. Patients with $\mathrm{CF}$ show adequate functional immune response to PA with regard to $\mathrm{IgG}$ antibodies to LPS of $\mathrm{PA}$. It is possible that vaccination against $\mathrm{PA}$ of $\mathrm{CF}$ patients who have not yet been colonized with PA could induce protective immunity. Safety and immunogenicity of PA polysaccharide Tox A conjugate vaccines in humans have been satisfactorily documented (34).

Acknowledgments. The authors thank Dr. H. Tschaeppeler for evaluation of the chest radiographs, Dr. R. Kraemer for performance of lung function studies, B. Born for technical assistance, and R. Ritzmann for secretarial services.

\section{REFERENCES}

1. Marks MI 1981 The pathogenesis and treatment of pulmonary infections in patients with cystic fibrosis. J Pediatr 98:173-179

2. Vasil ML 1986 Pseudomonas aenuginosa: biology, mechanisms of virulence, epidemiology. J Pediatr 108:800-805

3. Hoiby N, Döring G, Schiotz PO 1987 Pathogenic mechanisms of chronic Pseudomonas infections in cystic fibrosis patients. Antibiot Chemother 39:60-76

4. Pier GB 1985 Pulmonary disease associated with Pseudomonas aeruginosa in cystic fibrosis: current status of the host-bacterium interaction. $J$ Infect Dis 151:575-580

5. Fick RB 1989 Lung humoral response to Pseudomonas species. Eur J Clin Microbiol Infect Dis 8:29-34

6. Döring G, Hoiby N 1983 Longitudinal study of immune response to Pseudomonas aeruginosa antigens in cystic fibrosis. Infect Immun 42:197-201

7. Hollsing AE, Granström M, Vasil ML, Wretlind B, Strandvik B 1987 Prospective study of serum antibodies to Pseudomonas aeruginosa exoproteins in cystic fibrosis. J Clin Microbiol 25:1868 1874

8. Brett MM, Ghoneim ATM, Littlewood JM, Losowsky MS 1986 Development of enzyme linked immunosorbent assay (ELISA) to detect antibodies to Pseudomonas aeruginosa cell surface antigens in sera of patients with cystic fibrosis. J Clin Pathol 39:1124-1129

9. Breet MM, Ghoneim ATM, Littlewood JM 1987 Serum IgG antibodies in patients with cystic fibrosis with early Pseudomonas aeruginosa infection. Arch Dis Child 62:357-361

10. Hancock RE, Mouat ECA, Speert DP 1984 Quantification and identification of antibodies to outer-membrane proteins of Pseudomonas aeruginosa in sera of patients with cystic fibrosis. J Infect Dis 149:220-226

11. Dasgupta MK, Zuberbuehler P, Abbi A, Harley FL, Brown NE, Lam K Dossetor JB, Costerton JW 1987 Combined evaluation of circulating immune complexes and antibodies to Pseudomonas aeruginosa as an immunologic profile in relation to pulmonary function in cystic fibrosis. $\mathrm{J}$ Clin Immunol 7:51-58

12. Pedersen SS, Espersen F, Hoiby N 1987 Diagnosis of chronic Pseudomonas aeruginosa infection in cystic fibrosis by enzyme-linked immunosorbent assay. J Clin Microbiol 25:1830-1836

13. Moss RB, Hsu Y-P, Lewiston NJ, Curd JG, Milgrom H, Hart S, Dyer B, Larrick JW 1986 Association of systemic immune complexes, complement activation, and antibodies to Pseudomonas aeruginosa lipopolysaccharide and exotoxin A with mortality in cystic fibrosis. Am Rev Respir Dis 133:648 652

14. Fomsgaard A, Hoiby N, Shand GH, Conrad RS, Galanos C 1988 Longitudinal study of antibody response to lipopolysaccharides during chronic Pseudomonas aertiginosa lung infection in cystic fibrosis. Infect Immun 56:22702278

15. Schaad UB, Wedgwood-Krucko J, Suter S, Kraemer R 1987 Efficacy of inhaled amikacin as adjunct to intravenous combination therapy (ceftazidime and amikacin) in cystic fibrosis. J Pediatr 11:599-605

16. Kraemer R, Rüdeberg A, Kläy M, Rossi E 1979 Relationship between clinical conditions, radiographic findings and pulmonary functions in patients with cystic fibrosis. Helv Paediatr Acta 34:417-428

17. Chrispin AR, Norman AP 1974 The systematic evaluation of chest radiograph in cystic fibrosis. Pediatr Radiol 2:101-106

18. Kraemer R, Meister B, Schaad UB, Rossi E 1983 Reversibility of lung function abnormalities in children with perennial asthma. J Pediatr 102:347-350

19. Cryz Jr SJ, Fürer E, Germanier R 1983 Protection against Pseudomonas aeruginosa infection in a murine burn wound sepsis model by passive transfer of antitoxin A, antielastase, and antilipopolysaccharide. Infect Immun

20. Cryz Jr SJ, Pitt TL, Fürer E, Germanier R 1984 Role of lipopolysaccharide in virulence of Pseudomonas aeruginosa. Infect Immun 44:508-513

21. Liu PV, Matsumoto H, Kusama H, Bergan T 1983 Survey of heat-stable, major somatic antigens of Pseudomonas aeruginosa. Int $\mathrm{J}$ Syst Bacteriol $33: 256-264$

22. Fürer E, Cryz Jr SJ, Dorner F, Nicolet J, Wanner M, Germanier R 1982 Protection against colibacillosis in neonatal piglets by immunization of dams with prochloreagenoid. Infect lmmun 35:887-894

23. Laemmli UK 1970 Cleavage of structural proteins during the assembly of the head of bacteriophage T4. Nature 227:680-685

24. Towbin H, Stachelin T, Gordon J 1979 Electrophoretic transfer of proteins from polyacrylamide gels to nitrocellulose sheets: procedure and some applications. Proc Natl Acad Sci USA 76:4350-4354 
25. Tsai CM. Frasch CE 1982 A sensitive silver stain for detecting lipopolysaccharides in polyacrylamide gels. Anal Biochem 119:115-119

26. Cryz SJ. Sadoff JC, Ohman D, Fürer E 1988 Characterization of the human immune response to a Pseudomonas aeniginosa O-polysaccharide-toxin A conjugate vaccine. J Lab Clin Med 111:701-707

27. Sticritz DD. Holder IA 1975 Experimental studies of the pathogenesis of infections due to Pseudomonas aeruginosa: description of a burned mouse model. J Infect Dis 1 13:688-691

28. Matthews DE, Farewell VT (eds) 1985 Using and Understanding Medical Statistics. Karger. Basel, New York, pp 1-200

29. Fick RB, Olchowski J, Squier SU, Merrill WW, Reynolds HY 1986 Immunoglobulin-G subclasses in cystic fibrosis. Am Rev Respir Dis 133:418-422

30. Moss RB 1986 IgG subclasses in respiratory disorders: cystic fibrosis. Monogr Allergy 19:202-209
31. Moss RB, Hsu Y-P, Sullivan MM, Lewiston NJ 1986 Altered antibody isotype in cystic fibrosis: possible role in opsonic deficiency. Pediatr Res 20:453-459

32. Brandtzaeg P, Kett K, Rognum TO, Söderstroöm R, Björkander J, Söderström T, Petrusson B, Hanson LA 1986 Distribution of mucosal IgA and IgG subclass-producing immunocytes and alterations in various disorders. Monogr Allergy 20:179-194

33. Sawada S, Suzuki M, Kawamura T, Fujinaga S, Masuho Y, Tomibe K 1984 Protection against infection with Pseudomonas aeruginosa by passive transfer of monoclonal antibodies to lipopolysaccharides and outer membrane proteins. J Infect Dis 150:570-576

34. Cryz Jr SJ, Fürer E, Cross AS, Wegmann A, Germanier R, Sadoff JC 1987 Safety and immunogenicity of a Pseudomonas aeruginosa O-polysaccharide toxin A conjugate vaccine in humans. J Clin Invest 80:5I-56 